FHWA/IN/JTRP-2009/14

Final Report

ECONOMIC DEVELOPMENT PERFORMANCE MEASURES AND RURAL ECONOMIC DEVELOPMENT IN INDIANA

Jennifer L. Sharkey

Jon D. Fricker

April 2009 
Final Report

\title{
FHWA/IN/JTRP-2009/14
}

\section{ECONOMIC DEVELOPMENT PERFORMANCE MEASURES \\ AND \\ RURAL ECONOMIC DEVELOPMENT IN INDIANA}

\author{
By \\ Jennifer L. Sharkey \\ Graduate Research Assistant \\ Jon D. Fricker, P.E. \\ Professor of Civil Engineering \\ Joint Transportation Research Program \\ Project No. C-36-73LL \\ File No. 3-3-38 \\ SPR-3098 \\ Conducted in cooperation with the \\ Indiana Department of Transportation \\ and the \\ U.S. Department of Transportation \\ Federal Highway Administration
}

The contents of this report reflect the views of the author, who are responsible for the facts and the accuracy of the data presented herein. The contents do not necessarily reflect the official views of policies of the Indiana Department of Transportation or the Federal Highway Administration at the time of publication. This report does not constitute a standard, specification, or regulation.

Purdue University

West Lafayette, IN 47907

April 2009 
TECHNICAL REPORT STANDARD TITLE PAGE

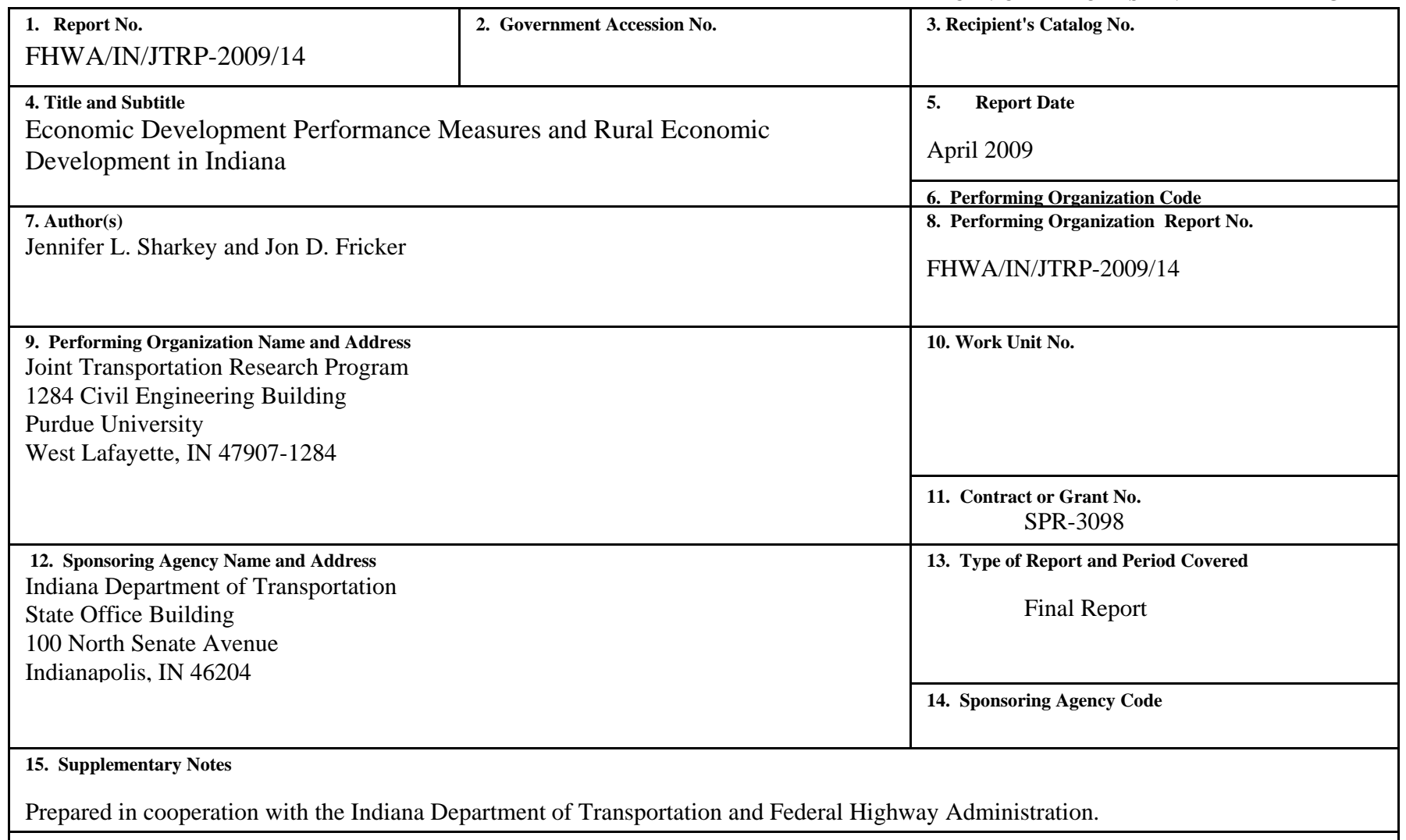

\section{Abstract}

An important consideration when identifying and implementing transportation investments is the prospect of economic development. Government agencies are faced with the challenging task of efficiently allocating scarce resources in order to satisfy the physical needs of the state and its communities. The Indiana Department of Transportation has the difficult task of prioritizing projects involving urban and rural transportation investments while attempting to satisfy both local and state needs. Typically, urban settings provide the greatest opportunity for economic development, due to population density, public infrastructure, and ready markets. Consequently, rural areas may get left behind, becoming more isolated and unattractive from a business and even residential standpoint. Therefore a study is needed to identify the methodology that can accurately evaluate the economic impacts of a transportation investment, with emphasis on rural Indiana.

A variety of performance measures could be used when evaluating a potential investment. This study has sought to identify and assess economic development performance measures to be used when evaluating transportation investments in rural Indiana. A list of the twelve most promising performance measures has been compiled, with a corresponding list of their advantages and disadvantages. The list provides a useful framework for economic analysis of rural transportation investments.

This study recognizes that further research is needed in order to provide a more robust conclusion regarding the link between transportation investment and economic development. The additional research would include individual case studies, county-level data analyses, and quality of life studies. Individual case studies would provide a 'real world' application for the economic development performance measures identified and can validate their use. Conducting a county-level data analysis would allow for quantitative comparisons to be made among counties based on need for economic development as well as the probability of development. The quality of life study would help to address issues that complement the economic development factors in a rural area. At the time this study was stopped, these investigations were underway. While the performance measure study provides a good beginning for economic studies, the additional research can help to enhance and refine the use of these measures.

\section{Key Words}

economic development, performance measures, transportation investment, rural Indiana, Indiana Department of Transportation, quality of life

\section{Distribution Statement}

No restrictions. This document is available to the public through the National Technical Information Service, Springfield, VA 22161

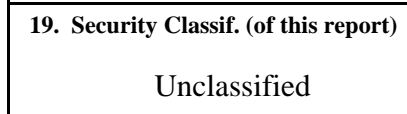

Form DOT F 1700.7 (8-69) 


\section{Table of Contents}

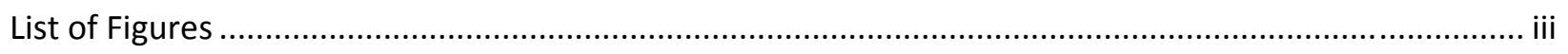

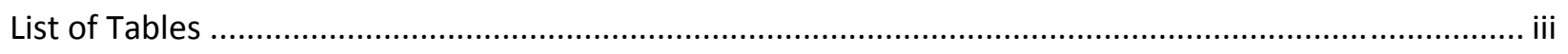

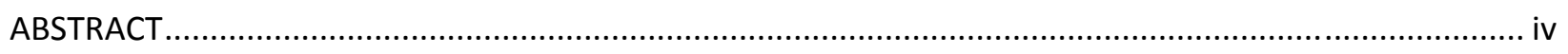

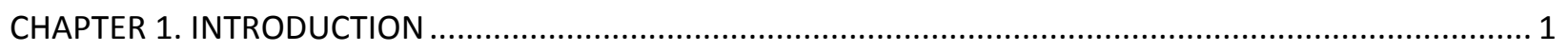

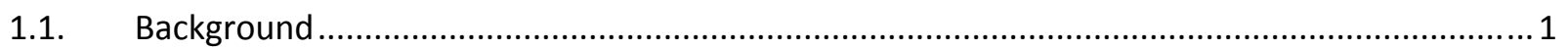

1.2. Motivation for Present Research Study ......................................................................... 1

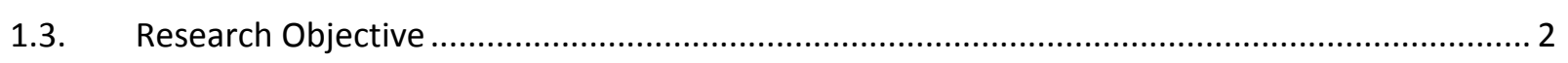

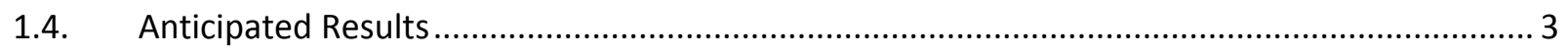

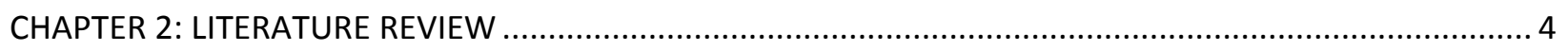

2.1 Important Studies Addressing Economic Development and Transportation .................................. 4

2.1.1. Economic Development Measures and Strategies ............................................................... 4

2.1.2. Economic Development Models Regarding Location Decision .............................................. 4

2.1.3. Statewide Analysis of Transportation and Economic Development...................................... 6

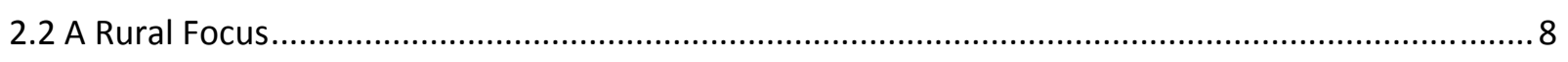

CHAPTER 3: ECONOMIC DEVELOPMENT PERFORMANCE MEASURES …............................................. 9

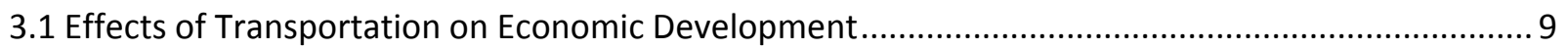

3.1.1. Economic Development Performance Measures Associated with Transportation................... 9

3.2. Evaluation of Economic Development Performance Measures .................................................. 11

3.2.1. Methodology of Performance Measure Evaluation ........................................................... 11

3.2.2. Results of Economic Development Performance Measure Evaluation ................................... 12

3.3. Refining the Tentative List of Performance Measures ............................................................. 17

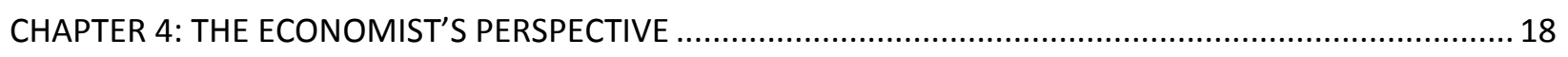

4.1. Purdue University's Center for Rural Development .............................................................. 18

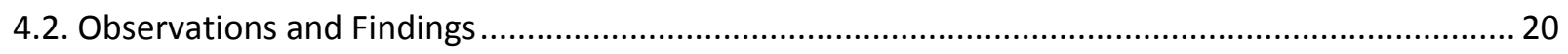

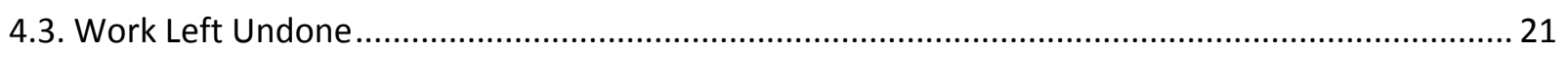

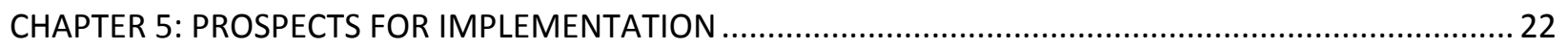




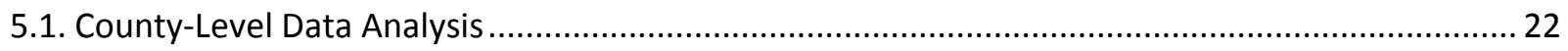

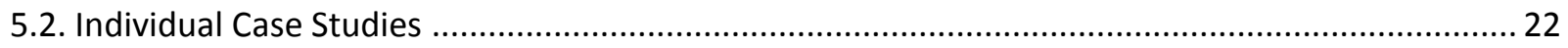

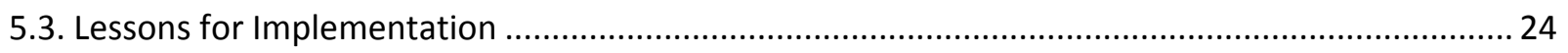

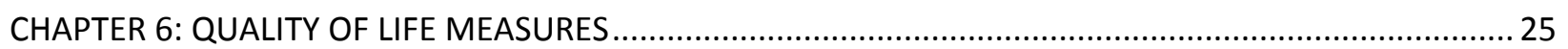

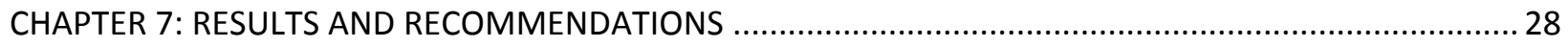

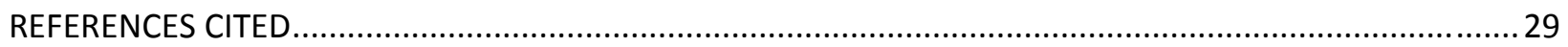

\section{List of Figures}

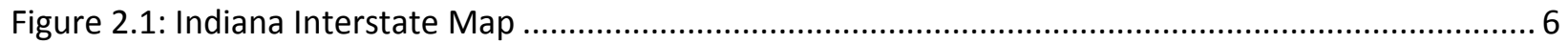

\section{List of Tables}

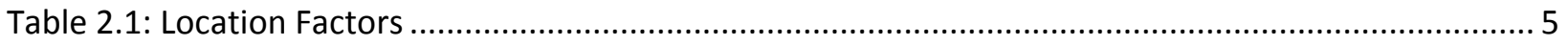

Table 3.2: Economic Development Performance Measure Matrix ........................................................ 12

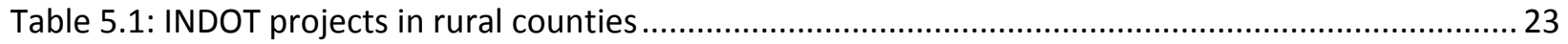

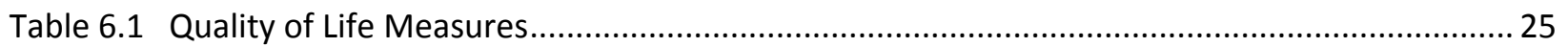




\section{CHAPTER 1. INTRODUCTION}

\subsection{Background}

It has long been a concern of transportation planners, decision-makers, and stakeholders to identify appropriate measures of performance for project selection and implementation. Improved, quicker, and more effective ways of decision making regarding transportation investment is essential due to limited funds. Government agencies need to determine the most efficient allocation of their resources in order to satisfy the needs of a state and its communities. Expected economic development impacts such as changes in the regional industry, commerce, agriculture and regional income typically drive the investment decision regarding major transportation projects. It is argued that, in rural areas in particular, transportation investments that enhance mobility and accessibility play a large role in rural development. Movement of agricultural products and residents to jobs and services is an essential part of rural life that transportation projects influence and enhance. Economic development specifically relates to the development of the economy of an area and the flow of dollars and jobs into that economy. Indications of change in an economy can be measured through the number of jobs that shift into or out of a community, and changes in wage rates and business output that are a result of transportation investment. The primary means of economic development are typically business startup, expansion, attraction and retention (Singh, Gkritza, and Sinha, 2007).

Economic development measures are one of the primary elements of economic analysis. These measures are essential for transportation planners and decision-makers, in the sense that economic development measures indicate (indirectly or directly) how well a transportation project or program realizes its economic development goals and objectives, whether they be quantitative or qualitative. Economic development measures typically center on four key objectives -- regional output, Gross Regional Product (GRP), wages, and employment. Additional measures may be used to complement these four key objectives to provide a more thorough analysis.

The next section discusses the motivations for the present research study.

\subsection{Motivation for Present Research Study}

The use of performance measures as a tool for evaluating the extent to which a transportation investment realizes its objectives is an important input in an agency's decision-making process. In particular, it has become increasingly important to monitor the performance of a transportation investment in achieving economic development goals. Transportation planners and decision-makers are in need of effective tools to enable them to identify the best combination of projects to enhance the economy of a region.

In addition to effective tools, policy-makers must also be equipped with the best information available regarding the advantages and disadvantages of various indicators of economic development and measuring economic activity. It is common to have multiple indicators to provide a thorough analysis of 
economic changes; however, these measures tend to be closely related and may provide different perspectives of the same type of economic change. An example of this effect is described below:

"Increased number of jobs in a region often has a strong correlation with higher wages, and higher income tax revenues. Increased capital investment in a region is also often associated with increased property values, and higher levels of tax revenue from businesses and from property tax. As such, impact evaluation by simple addition of the individual impacts may lead to double-counting (Singh, Gkritza, and Sinha, 2007)." From this example, it is clear to see why transportation agencies must have information available on which measures of economic development impacts are useful for certain types of evaluation of transportation projects or programs and geographic locations.

When selecting among the available economic development measures, several factors must be considered, including the availability of information, the usefulness for public information, and the usefulness for decision-making (Singh, Gkritza, and Sinha, 2007). The purpose of the highway project, type of project, as well as the impact area must also be considered when selecting economic development indicators.

Due to increasing complexity of transportation projects, as well as shrinking funds available for projects and programs, research is needed to build upon previous work regarding economic development. Specifically, issues and limitations of current state-of-the-art practices on selecting indicators for measuring economic development effects of transportation investments must be examined.

\subsection{Research Objective}

The previous section introduced the issues that indicate the need for a study on selecting economic development measures for performance monitoring and transportation investment selection. Research is needed to enhance the existing information base and identify the advantages and disadvantages of various economic development performance indicators. The main focus for this study is to identify robust indicators for measuring the changes in economic activity as well as directing the process for selecting appropriate measures. In particular, special attention will be directed to economic development in rural areas and how it can be measured.

In addition to a literature review of previous research in the area of economic development, this study will address what is feasible in the context of the State of Indiana and will focus on economic development in rural areas and how it can be measured. Rural Indiana faces many challenges related to demographic changes, job creation, capital access, infrastructure, land use, and environmental changes. Economic development of these areas is a subject that has not received much attention, but is becoming a subject of considerable interest. By studying the relationship between transportation investment and economic development in rural areas, the Indiana Department of Transportation (INDOT) planning personnel will be able to make more informed decisions on the planning and implementation of transportation projects. 


\subsection{Anticipated Results}

This study will focus on the potential of rural areas in Indiana to expand, attract, and retain businesses, based on historical data of performance and regional economic conditions (Singh, Gkritza, and Sinha, 2007). There are several ways in which this study can be used. First, this study will provide guidelines to INDOT to assist personnel in identifying economic development measures based on factors such as purpose, type, impact area, and usefulness of a project. Second, the selected measures can be used to select projects that will increase the efficiency of the transportation investment. Finally, focusing the analysis on rural areas will improve the judgment of planners and decision-makers when deciding whether, when, and to what extent a proposed transportation investment will yield economic benefits to the rural communities it serves. As a result, the final product of this study will demonstrate the value of investing in transportation corridors to support rural economic growth. 


\section{CHAPTER 2: LITERATURE REVIEW}

\subsection{Important Studies Addressing Economic Development and Transportation}

Economic development is an important issue for all regions, counties, and states. There is much literature available addressing this matter. However, the link between transportation and economic development is an issue that has yet to be understood, particularly in the rural sector. The following sections discuss previous research regarding the correlation between transportation and economic development.

\subsubsection{Economic Development Measures and Strategies}

Economic development is often a confusing term to define as well as to measure. There are many different ways to interpret economic development and to measure impacts associated with development. This makes evaluation of transportation investments difficult and unclear, both from an agency and a public viewpoint. Agencies become involved in economic analysis in several different ways through general investment programs, special economic development programs, regulatory involvement, and evaluation or education (Weisbrod, 2000). It has become a popular practice to use performance measures to evaluate the economic benefits of a transportation investment. The National Cooperative Highway Research Program (NCHRP) has conducted several surveys and studies to identify and define these measures. As discussed in NCHRP Synthesis 290, impact measures are used in a variety of ways to measure economic development. "The ways in which economic development impacts are being measured differs depending on the use to be made of the results-either for communicating to the public or for agency decision making" (Weisbrod, 2000). In addition to usage concerns, other concerns regarding performance measures include the availability of data and ease of interpretation.

It is worth noting that economic development practices and policies are generally designed to improve the quality of life in an area by increasing the following economic development measures: income, job choices, activity choices, stability, and amenities (Weisbrod and Forkenbrock, 2001). This conclusion introduces another topic of interest that needs further research and analysis -- quality of life. However, economic development impacts will continue to be the primary focus of this research.

\subsubsection{Economic Development Models Regarding Location Decision}

Few studies have been performed that evaluate community development strategies of rural areas. Of the studies reviewed, many discuss factors used for location decisions related to manufacturing firms or food processing facilities. Out of five studies reviewed, at least three indicated that rural areas are at a disadvantage when trying to attract new business. "The new economy we are in favors big cities over small ones and rural areas" (Urbanophile, 2008). One study conducted by Urbanophile discusses a new approach to regional economic development in Indiana that includes a metro-centric type of thinking that focuses on the centrality of cities. An example of this approach is Anderson, Indiana. The City of Anderson is located 26 miles northeast of Indianapolis, but has yet to integrate with the rapidly 
expanding metropolis. While its southern neighbors are growing and expanding its economic presence, Anderson continues to struggle. With the huge loss of manufacturing jobs, Anderson is in a state of rebuilding. The city had a chance to incorporate its economy with Indianapolis by having a joint airport with Fishers, one of Indy's largest growing and wealthiest areas, but it declined. If Anderson would have adopted the metro-centric approach to development and agreed to the joint airport, the economic benefits may have significantly helped the economically struggling city (Urbanophile, 2008). It would have encouraged those businesses that are already expanding north of Indianapolis into the metro suburbs of Caramel and Fishers to continue expansion into Anderson. Spinoff businesses and increased traffic flow through Anderson would have helped turn around the economic decline that it is currently experiencing.

While economic integration with nearby urban areas may be a solution for some rural areas, those that are located a great distance from metropolitan areas are not able to directly incorporate with a metropolis. Instead of focusing on the centrality of cities, McNamara and Kriesel (1991) focused on manufacturing recruitment and the factors used for location decisions. Their study acknowledged the uniqueness of rural communities, and evaluated each county based upon existing conditions, rather than evaluating the potential of metropolitan integration. An ordered, categorical logit model of plant attraction of Georgia counties was used to evaluate the probability of a county's attractiveness and how it can be altered by changes in location factors. Data for 158 Georgia counties were used in the model, as well as the location factors listed in Table 2.1.

Table 2.1: Location Factors

\begin{tabular}{ll}
\hline Non-Controlled Location Variable & Definition \\
\hline WAGE & The county's avg. weekly manuf. wage (\$) \\
UNEMP & Unemployment rate (\%) \\
WORKERS & The number of manuf. employees \\
MILES & Mileage of interstate highway in the county \\
RACE & Percentage of black residents \\
COLLEGE & Distance from county's center to a city with more than \\
& 2,000 college students \\
\hline Community-Controlled Location Variable & Definition \\
\hline SCHOOL & Percentage of students who complete high school \\
FPR & Fire protection rating; $1=$ highest, $10=$ lowest \\
FREEPORT & Dummy variable for passage inventory tax exemption; \\
& $1=y e s, 0=$ no \\
TAX & The county's effective tax rate per $\$ 1,000$ of property $(\$)$ \\
PRICE & The predicted per-acre price of the county's best industrial \\
& site $(\$)$ \\
\hline
\end{tabular}


As the table indicates, factors are separated into non-controlled and community-controlled variables. These categories help county public decision-makers identify factors that can be altered through county policy to increase the probability of attracting a manufacturing plant. It is noted that transportation factors are not prominent in this model. Only mileage of interstate highway in a county is included. This does not indicate that infrastructure is not a critical factor for location decision; it only shows that infrastructure is one of many factors used to determine site selection for manufacturing facilities. In a report entitled Recruiting Manufacturing Firms as a Community Development Strategy (McNamara and Kriesel, 1991), interstate access played a large role in plant investment. "The State [Indiana] attracted 141 new plant investments...Forty counties did not attract new manufacturing investment in the 19861989 period-most are rural counties in southern and West Central Indiana" Referring to the map in Figure 2.1, southern and west central Indiana are at a disadvantage with regard to access, due to the lack of interstate highways within the area. Allen, Madison, Marion, and Wayne counties were reported to have attracted the greatest number of manufacturing firms. These counties have good interstate access, which may have played a large role in site selection. This concept is illustrated in Figure 2.1 which shows the Indiana Interstate System (solid red lines) with each of the four counties (stars); Allen, Madison, Marion, and Wayne. As shown, Marion County has the greatest concentration of interstate systems, by virtue of being located in the center of the state, where Interstates I-65, I-69, I-70, and I-74 all converge on Indianapolis, some using I-465. This system allows for a high volume of vehicles to pass through Marion County each day, increasing the opportunity and need for economic development. With such a great highway infrastructure, businesses have transportation routes readily available for supply shipments and other operating activities. The same concept is true for the other three counties. Allen County and Madison County contains Interstate 69, a major north-south transportation route, and Wayne County claims Interstate 70, a vital east-west transportation route. With accessible interstate systems located within the area, each county was able to attract a number of manufacturing firms by offering superior transportation infrastructure when compared to other Indiana counties, such as those located south-central Indiana.

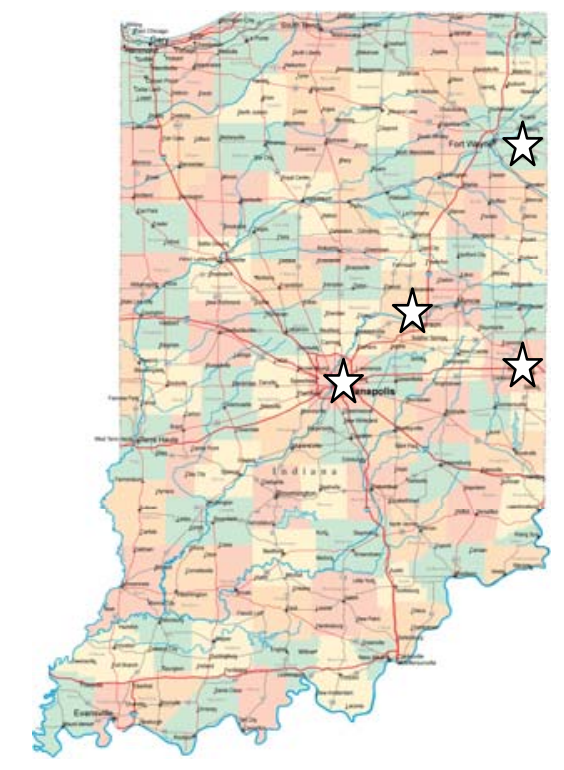

Figure 2.1: Indiana Interstate Map

\subsubsection{Statewide Analysis of Transportation and Economic Development}

The studies reviewed thus far have dealt with economic development within rural regions, but have not focused solely on transportation investment. It is of great interest to the Indiana Department of Transportation as well as other Departments of Transportation (DOTs) to evaluate this link between transportation investment and economic development. With more and more transportation projects being proposed and funding requested, it has become a difficult task for decision-makers to prioritize and rank investments; particularly when distinguishing between rural and urban transportation projects. A recent study conducted by Gkritza et al. (2006) explored this issue in great detail. The report, entitled Economic Development Effects of INDOT Transportation Projects, explored the link between investment and economic development on a statewide level. A set of seemingly unrelated regression equations 
(SURE) was developed to assist INDOT personnel at the project development phase to estimate the statewide long-term economic effects of highway investment in Indiana. Improvement types that were considered for analysis included added travel lanes, median construction, new interchange construction or modification, new alignments, and bypass projects. The study consisted of four main steps; (1) determining which factors were important and how they could be measured, (2) obtaining data at a geographic scale consistent with the economic variables, (3) estimating the long-term economic development effects of different types of highway stages, and (4) developing analytical methodology that included multiple variables in order for effective use by stakeholders. This study has more specific objectives; using a regional scope is used when looking at economic development, with an emphasis on rural regions (identified as counties). The process and background information provided in Gkritza's work provides a theoretical methodology for economic analysis, yet lacks practical applications for rural objectives. The following paragraphs outline the steps used by Gkritza to develop the theoretical methodology.

Step 1: Performance Measures

Before evaluation of investments could be performed, economic development performance measures had to be identified and evaluated. Through Gkritza's research, four economic development measures were identified: (1) net change in employment, (2) net change in income, (3) net change in output, (4) net change in gross regional product (GRP). When selecting the appropriate measures for a statewide analysis, certain criteria had to be fulfilled, such as the availability of data, usefulness for public information, usefulness for decision-making, purpose of highway project, type of project, and impact area (Gkritza, Labi, and Sinha, 2006).

Step 2: Data Collection

Data collection in this context involves gathering information on a number of factors hypothesized to affect economic development. Most often, data collection is the sole obstacle to an economic analysis. For the Gkritza study, two types of factors were used: highway project-specific factors (type, size, etc.) and location-specific factors. For the improvement types listed previously (added travel lanes, median construction, etc.), 117 individual highway improvement projects were identified from Indiana's 25-Year Long-Range Plan and considered for economic analysis. Of the 117 projects, 55 were recognized as rural projects, with the remaining 62 projects classified as urban. This indicates that location was taken into account during the analysis.

Step 3: Long-Term Regional Economic Development

Long-term regional economic development has typically been analyzed by INDOT using a program known as REMI (Regional Economic Model, Inc). It is the most widely used economic simulation model for transportation-related applications (Gkritza, Labi, and Sinha, 2006). The model is dynamic and accounts for long-term economic, industrial, and demographic changes, as well as changes in business costs over time. It consists of five basic blocks: (1) output, (2) labor and capital demands, (3) population and labor supply, (4) wages, prices and prices, and (5) market shares. The model was run several times using data collected from the 117 transportation improvement projects to obtain variables used to determine economic output. 
Step 4: Analytical Methodology

The previous three steps built the foundation for the development of an analytical methodology. This methodology created by Gkritza et al. included econometric models that were used to investigate the relationship between benefit measures, project attributes, and location attributes. Simultaneous models were used instead of simple models due to the complexity and correlation of variables. Several statistical tests including ordinary least squares, t-student statistic, Chow test, and f-statistic were used to evaluate the type of model used (simple vs. simultaneous) as well as the variables used in the analysis. One of the objectives of Gkritza's study was to provide "order-of-magnitude estimates of longterm economic development effects of highway investment in Indiana by project type and location attributes." To achieve this, a system of SURE (seemingly unrelated regression equations) was developed to investigate the relationship between a certain type of highway investment and statewide long-term changes in economic development under two different scenarios of business attraction (Scenario 3 and Scenario 4). Scenario 3 includes the potential of business attraction proportional to that of business expansion by a factor of $L Q$ (Location Quotient). The factor of $L Q$ allows for location to be a quantifiable term in this step. Scenario 4 refers to potential business attraction for rural projects. Each type of transportation investment was analyzed using the system of SURE equations to assess impacts on statewide economic development over a 20-year period. This allows for the determination if the overall benefits justify their costs. When analyzing the "added travel lanes" type of transportation improvement, it was found that "adding travel lanes to a highway in rural areas.... with a less developed transportation system will have a larger impact than a similar project introduced into an urban area with a mature system" (Gkritza, Labi, and Sinha, 2006). This conclusion reinforces the need for additional research in the area of rural transportation investment and the need for an efficient evaluation methodology of investments for use by DOT officials.

\subsection{A Rural Focus}

The evaluation tool developed by Gkritza et al. analyzes investments on a statewide scale. What this tool lacks, and what the present study seeks the framework for, is the ability to assess economic impacts on a community or regional-level to identify the effects created by a transportation investment. The following chapter provides the building blocks for a quantitative tool to be developed to assess rural transportation investments and the direct economic impacts associated with a community or region. 


\section{CHAPTER 3: ECONOMIC DEVELOPMENT PERFORMANCE MEASURES}

\subsection{Effects of Transportation on Economic Development}

Transportation can be a key element in the development of a community. Recently, attention has been devoted to the effects transportation investments have on where people live and where businesses locate. The questions that decision-makers ask are typically two sided: (1) What is the effect of transportation on additional economic development? (2) What are the transportation needs of future growth? (Eberts, 2000) In order to answer these questions, four factors must be examined: (a) type of transportation investment, (b) available data necessary to analyze the economic effect, (c) appropriate methodology for an economic analysis, and (d) proper interpretation and explanation of the results. This section will look at the third factor--appropriate methodology for economic analysis.

\subsubsection{Economic Development Performance Measures Associated with Transportation}

Choosing the appropriate methodology for evaluating transportation investment can be difficult. Many variables are involved when determining the cause of economic development. Factors such as a new transportation investment, a new business locating in the area, or policy incentives such as tax breaks can ignite the growth of an economy. To effectively assess each investment, evaluation tools such as performance measures or indicators should be utilized.

Many economic development performance measures have been identified and used. However, not all measures apply to each type of investment. Factors such as geographic location, type of investment, and purpose of investment may determine which economic development performance measures are best suited for each situation. Identifying which measures apply to transportation projects is the first step in an economic analysis. Provided below is a list of measures used to evaluate economic development that were identified from a thorough literature search, with a corresponding definition. Some measures may have a customized definition in addition to the generic definition. For this project, rural regions are the areas of interest. In order to accurately apply each performance measure to this study, definitions may be adapted to reflect use in a rural setting. The terms "localized" and "statewide" will distinguish which geographic area the definition supports.

Business Expansion: Business expansion can come in many forms. Four categories are: (1) sell more of the same, (2) expand the range of products or services sold, (3) sell something very different, and (4) change the underlying business concept (Hillstrom, 2005). With each of the four categories, facility and employment expansion would be necessary to accommodate business growth. For this study, the term 'business expansion' will indicate physical expansion as well as employment expansion of an existing firm within a rural community.

Business Retention: Business retention, similar to expansion, can be defined in many ways. In this context, retention is defined as the number of existing businesses that remain in a rural community 
years after the business has been established. The user identifies the threshold used for number of years, depending on many factors, such as type of business or industry.

Capital Investment: Capital investment is the monetary contribution a firm or business brings to a community. A firm that would make only a modest investment, such as purchasing furnishings for rented office space, would be less attractive than a business that would either build or purchase a major facility. By providing a large capital investment, it is indicated that the firm or business is planning on a long-term involvement within the community (Weisbrod and Forkenbrock, 2001). Transportation capital investments could include lane expansion, re-surfacing, or widening.

Economic Stability: How sensitive is the local economy to fluctuation in certain sectors of the regional and national economy? Does the level of jobs and income in an area change more frequently and more significantly than the state economy? This measure indicates the vulnerability of an area to economic downturns resulting from over-reliance on mature industries and those that are subject to severe business-cycle fluctuations (Weisbrod and Forkenbrock, 2001). A related measure may be some assessment of the degree to which the local economy is diversified.

Number of Activities: The more activities a community has, the more attractive the community becomes to local residents as well as outside travelers. The term 'activities' includes all variables corresponding to opportunities for shopping, dining, as well as social and entertainment activities in (or accessible to) the community (Weisbrod and Forkenbrock, 2001). This may also include special amenities, such as cultural or recreational facilities. For example, activities located in or near the small town of Angola, Indiana include Pokagon State Park, YMCA, Prime Outlet Mall, local parks, theaters, restaurants, bars, and recreational rentals for boats and other watercrafts.

Number of Businesses: Comparable to the definition of 'activities', the term 'businesses' refers to all establishments that provide retail, commercial, and industrial services.

Number of Jobs: A job is any "regular activity that is performed in exchange for monetary payment (Farlex, 2008)."

Total Income: Total income on a localized scale refers to the collective income of all workers living within the specified rural community. On a statewide level, this definition would be inadequate, because a significant income increase for one rural area in Indiana would not be detectable on the larger scale. To account for this problem, a different definition is needed. For a statewide scale, total income refers to the collective income of all workers and employees within the specified area. Although employees of a rural community may live elsewhere and spend the disposable income in their living community, the state as a whole prospers due to the income increase.

Average Income: This measure has a structure similar to the total income measure. Two definitions are appropriate for average income to distinguish between a localized and statewide scope. For a localized analysis, average income is calculated by dividing the total income of workers in a community by the 
number of workers in the rural area. For a statewide scope, average income would include workers AND employees of a specified rural area.

Output per Capita: This measure refers to the amount of output (sales revenue) a community produces divided by the number of employees in that community.

Property Appreciation: Property appreciation refers to the increase in the value of land and improvements located within the community.

Absolute Amount of Poverty in an Economy: For this measure, the percentage of households under the poverty threshold will be used to determine the absolute amount of poverty in that community. The poverty threshold is defined as the minimum level of income deemed necessary to achieve an adequate standard of living. According to the Health and Human Services Poverty Guidelines, the US 2007 poverty threshold for a single person under the age of 65 is US\$10,210 (The Network, 2007).

\subsection{Evaluation of Economic Development Performance Measures}

Many measures may be used to evaluate the effects a transportation investment has on economic development of a community. The validity of each measure must be tested in order to determine which indicators are best used in varying situations. While one measure may provide valuable information, using a single indicator to facilitate resource allocation is probably not an effective practice. Each performance measure has some sort of limitation that must be compensated for by another indicator. Understanding the limitations of each measure will help provide government officials and decisionmakers with the knowledge needed to select appropriate indicators for a given investment type. The following sections discuss the methodology used to evaluate the measures introduced in the previous section and identify the advantages and disadvantages associated with each indicator.

\subsubsection{Methodology of Performance Measure Evaluation}

Evaluating performance measures is an essential part of the total economic analysis. Each performance measure has some sort of limitation, whether it is availability of data, interpretation of results, or subjectivity of the measurement. In order to determine the advantage and disadvantage for each measure, a literature search and discussions with personnel in the transportation and economic development field were undertaken. Many transportation agencies already incorporate some sort of performance measurement in their analyses and have identified some restrictions of measures due to first-hand experience. For example, in April of 2002, the University of South Florida Center for Urban Transportation Research conducted an email survey on behalf of the Florida Department of Transportation (DOT). This survey was designed to develop performance measures for community impact assessments. Individuals involved in the survey included those from various public transportation agencies, other state DOTs, metropolitan planning organizations, and transit agencies (Ward, 2005). As a result, measures were identified for various categories, including economic development. The Colorado DOT performed a similar evaluation; however, the performance measures identified for economic development were divided into quantifiable and non-quantifiable indicators 
(Pickton, Clements, and Felsburg, 2007). Many measures identified by each DOT matched those that had already been included in this study. In addition to the FDOT and CDOT examples, other state DOT practices were assessed. Using similar evaluation techniques, the economic development performance measures identified for this study were analyzed. Input from literature results, as well as from experts at the Indiana Department of Transportation, Purdue University, and various planning organizations was compiled and included in this report. The next section identifies advantages and disadvantages for each performance measure, with emphasis on the applicability each PM has to rural areas.

\subsubsection{Results of Economic Development Performance Measure Evaluation}

The matrix shown in Table provides a summary of the advantages and disadvantages for each performance indicator.

Table 3.1: Economic Development Performance Measure Matrix

\begin{tabular}{|c|c|c|c|c|}
\hline $\begin{array}{l}\text { Performance } \\
\text { Measure }\end{array}$ & Description & Source/Reference & Advantages & Disadvantages \\
\hline Business expansion & $\begin{array}{l}\text { Number of new businesses attracted to } \\
\text { the area }\end{array}$ & NCHRP Report 456 & $\begin{array}{l}\text { 1. Reveals attractiveness } \\
\text { of community to business } \\
\text { 2. Data can be obtained }\end{array}$ & \\
\hline Business retention & $\begin{array}{l}\text { Median number of business years } \\
\text { (average number of years businesses } \\
\text { operating in community) }\end{array}$ & NCHRP Report 456 & $\begin{array}{l}\text { Reveals attractiveness of } \\
\text { community to business }\end{array}$ & Interpretation may vary \\
\hline Economic stability & $\begin{array}{l}\text { 1. Gross Regional Product } \\
\text { 2. Stability of number of jobs and } \\
\text { income }\end{array}$ & NCHRP Report 456 & $\begin{array}{l}\text { Indicates community } \\
\text { stability }\end{array}$ & $\begin{array}{l}\text { 1. Difficult to measure } \\
\text { 2. Interpretation may } \\
\text { vary }\end{array}$ \\
\hline $\begin{array}{l}\text { Number of } \\
\text { activities }\end{array}$ & $\begin{array}{l}\text { Includes retail, entertainment, } \\
\text { commercial, and hospitality }\end{array}$ & NCHRP Report 456 & $\begin{array}{l}\text { 1. Data are easily obtained } \\
\text { 2. Reveals amenities } \\
\text { within the area }\end{array}$ & $\begin{array}{l}\text { Can be subjective in } \\
\text { measurement }\end{array}$ \\
\hline Number of jobs & $\begin{array}{l}\text { Number of new jobs created within (or } \\
\text { accessible to) an area }\end{array}$ & NCHRP Synthesis 290 & $\begin{array}{l}\text { 1. Easy to measure } \\
\text { 2. Direct relationship }\end{array}$ & $\begin{array}{l}\text { May not distinguish } \\
\text { between basic and } \\
\text { service jobs }\end{array}$ \\
\hline Total income & $\begin{array}{l}\text { Total income earned by workers in a } \\
\text { community }\end{array}$ & NCHRP Synthesis 290 & $\begin{array}{l}\text { Easy to measure (where } \\
\text { data are available) }\end{array}$ & $\begin{array}{l}\text { May not reflect average } \\
\text { income per worker }\end{array}$ \\
\hline Average income & $\begin{array}{l}\text { Total income earned by workers in a } \\
\text { community divided by the total number } \\
\text { of workers located in the community }\end{array}$ & NCHRP Synthesis 290 & $\begin{array}{l}\text { Easy to measure (where } \\
\text { data are available) }\end{array}$ & \\
\hline Output per capita & $\begin{array}{l}\text { Total output created in a community } \\
\text { divided by the number of employees of } \\
\text { that community }\end{array}$ & $\begin{array}{l}\text { Department of Economics, } \\
\text { University of Washington }\end{array}$ & $\begin{array}{l}\text { 1. Monetary value } \\
\text { 2. Data are easily } \\
\text { accessible }\end{array}$ & $\begin{array}{l}\text { May not show the actual } \\
\text { employment state of the } \\
\text { community }\end{array}$ \\
\hline $\begin{array}{l}\text { Absolute amount } \\
\text { of poverty in an } \\
\text { economy }\end{array}$ & $\begin{array}{l}\text { HHS poverty guidelines for } 2007 \\
\text { indicates that the threshold for a single } \\
\text { person under the age of } 65 \text { is } \\
\text { US\$10,210 }\end{array}$ & $\begin{array}{l}\text { Department of Economics, } \\
\text { University of Washington }\end{array}$ & $\begin{array}{l}\text { 1. Easily obtained through } \\
\text { databases } \\
\text { 2. Standardized threshold } \\
\text { across the country }\end{array}$ & $\begin{array}{l}\text { Does not indicate } \\
\text { community profile } \\
\text { (wealthy area vs. poor } \\
\text { area) }\end{array}$ \\
\hline
\end{tabular}

Many of these measures have both advantages and disadvantages that must be discussed in more detail

for a comprehensive understanding. 


\section{Business Expansion}

Advantages:

Reveals attractiveness of community to businesses. If a rural setting is undesirable for economic development, it will be evident by the lack of businesses in that rural sector. Using business expansion as an indicator, the tendency of businesses to locate in that area can be illustrated.

Data can be obtained. Collecting accurate data is one of the biggest problems when examining economic development. Without sufficient data, analyses cannot be performed and results cannot be obtained. To measure business expansion, data can be obtained through various outlets such as the business itself, the United States Census Bureau, or other statistical agencies such as STATS Indiana.

\section{Business Retention}

Advantage: Reveals attractiveness of community to businesses. Similar to business expansion, the desirability of a rural sector can be determined by the number of businesses that continue to locate and operate in the area.

Disadvantage: Interpretation may vary. Unlike business expansion, it may be difficult to determine what 'retention' indicates. Depending on the time frame, a different outcome could result. Does a business that has been operating for 3 years in the area qualify? Or is a longer duration, such as 20 years, required? Determining a duration threshold would be the first step in identifying business retention.

\section{Capital Investment}

Advantage: Distinguishes between short-term and long-term investment. Capital investment is a broad phrase that encompasses many aspects of economic development. One underlying theme is that capital investment can have a short-term or long-term impact. For this application, a short-term investment, such as renting an office space or purchasing furnishings for an office, may have less weight than a longterm investment, including the purchase of a major facility or the construction of a new one. This measure would identify and separate the two investments, providing a more detailed analysis of economic development.

Disadvantage: Can be difficult to measure. When an area becomes more productive and attracts business activity, an increase in investment is often accomplished through new start-up businesses, relocation of outside businesses to the area, or expansion of current businesses (Weisbrod and Forkenbrock, 2001). To measure the actual increase in investment, construction spending could be used, as well as improvement in productivity of businesses due to investment in new equipment. Additional measures could include investment in land and buildings. Determining what to measure to use and how to use it is challenging and often discouraging when addressing capital investment.

\section{Economic Stability}

Advantage: Indicates community stability. As the economy of a rural area becomes more diversified, the stability of jobs and income tends to increase. A stable economic condition reduces the area's vulnerability to economic downturns that occur from over-reliance on select industries, especially those subject to severe business-cycle fluctuations (Weisbrod and Forkenbrock, 2001). An example of this 
effect would be the town of Anderson, Indiana. Due to heavy reliance on automobile manufacturing, the town's economy tends to fluctuate with the automobile industry. This over-dependence results in an unstable economy, as employees may be laid-off and plants may be closed due to the overall automobile industry.

\section{Disadvantages:}

Difficult to measure. Unless it is known what industry will be attracted to the area, it is difficult to determine the impacts of a new industry to a community.

Interpretation may vary. Due to a lack of a consistent measure of economic stability, interpretation of the indicator could pose a problem when communicating among various stakeholders. Views may conflict when considering what is "stable" in regards to jobs and income and whether that steadiness is increasing, decreasing, or remaining the same.

\section{Number of Activities}

\section{Advantages:}

Data are easily obtained. Data regarding the number of activities are relatively easy to collect using field observations, county records, as well as surveys of residents.

Reveals amenities within the area. Collecting data regarding activities in (or accessible to) the area under analysis helps to expose all amenities located within the region. In this context, amenities are defined as a tangible benefit that increases the attractiveness or value of a community. Discovering the activities located within an area allows for a more detailed picture to be created regarding the social atmosphere and the accessibility of the community and surrounding areas.

Disadvantage: Subjective in measurement. Consistent with measures that relate to the quality of life of a community, subjectivity becomes an issue. If all decision-makers and stakeholders have a different understanding of what constitutes an 'activity,' an inconsistent analysis could result.

\section{Number of Businesses}

Advantages:

Data are easily obtained. To determine the number of businesses within an area many sources can be used. Field observations, county records, or alternate databases could yield the necessary information for this performance measure.

Reveals amenities within the area. Similar to the advantage of the "number of activities" performance measure, the number of businesses measure allows for an 'outsider' to map out the availability of amenities for the rural community. Identifying local amenities can aid an individual in quantitatively assessing the attractiveness or value of a community. 


\section{Disadvantages:}

May not reveal quality of business. Determining the number of businesses in an area can provide an overview of the attractiveness of a community, but it does not offer a clear understanding of the types of businesses located within the area. For example, would a rural area with a few gas stations, fast food chains, and dollar stores provide the same quality of life as one with a Wal-Mart, chain restaurants, and auto manufacturer even if the number of businesses were the same? Quality of businesses needs to be addressed to prevent a skewed viewed of a rural community.

Hard to determine temporary versus permanent business investment. When determining the number of businesses in an area, the issue of temporary or permanent business investment is often overlooked. Depending on when the analysis is performed, the actual number of functional businesses could fluctuate. Take a Farmer's Market, for example. This business is a seasonal (temporary) business which may not have a significant impact on a community when looking at long-term economic development. While the market provides income to local residents (farmers), it does not provide a steady income opportunity. Another example would be outlet malls. These facilities provide a physical structure for businesses, but do not necessarily have all rental units occupied. Also, outlet mall tenants do not always stay in the area for an extended period of time.

\section{Number of Jobs}

\section{Advantages:}

Easy to measure. Many times when a new business moves into an area, it provides a forecast of the number of jobs the business will bring to the community. Any business or agency would be able to provide the number of workers that company has employed at a given time.

Direct relationship. Number of jobs is most easily comprehended by the public because it directly relates to individuals. Employment provides opportunities for residents to experience income growth, increased personal well-being, and a higher quality of life.

Disadvantage: May not distinguish between basic and service jobs. Similar to the disadvantage as the "number of businesses" performance measure, this measure does not include separating between basic and service jobs. A service job would be one whose goods and services stay within the rural area where a basic job provides goods and services not only within the community but outside the rural area as well.

\section{Total Income}

Advantage: Easy to measure (where data are available). Obtaining data is the most difficult aspect of this performance measure. Once the data are collected, extracting the total income earned by employees and/or residents of the community is relatively straightforward.

Disadvantage: May not reflect average income per worker. It should be noted that this performance measure only takes into account the total wages earned in a community, not the average income per worker. A rural area could have a few wealthy families living in the area, which would raise the total 
income earned in the community. These families may not redistribute the income back into the community, but instead spend their disposable income in nearby metropolitan areas.

\section{Average Income}

Advantage: Easy to measure (where data are available). Data can be the most challenging part of an analysis. For this measure, once the data are collected, determining the average income for a community is easily calculated.

Also, the average income performance measure illustrates the mean income within the rural area. This measure, used in conjunction with "total income" measure, provides a more detailed picture of the community.

\section{Output Per Capita}

Advantages:

Monetary value. Once the term 'output' is defined, this measure provides a simple, easily understood outcome.

Data are easily accessible. Many sources could be used to obtain output data. Once a definition of output has been determined, appropriate steps can be taken to collect the necessary data.

Disadvantage: May not show the actual employment state of the community. As with the total income performance measure, output per capita could lead to a skewed view of the community. This view can result from manufacturing companies becoming more efficient by using machinery rather than labor. While output would continue to increase for that company and the community, the actual state of the rural area could decline due to layoffs and unemployment.

\section{Property Appreciation}

Advantage: Data are available on a consistent basis between counties. Appraisals of property values are conducted at regular intervals for purposes of setting property tax rates. Although there is some subjective judgment involved, county appraisers must follow guidelines established by the state. These assessed valuation data can be used to determine whether particular parcels have appreciated in value, or how the property values in an area of interest have changed. Other sources of property values are real estate agencies in the area. Looking at local property tax revenue could reveal if property has appreciated, subject to state-imposed property tax levy increase limits.

Disadvantage: Data may cover a short time frame and be inconsistent over time. By law, in the State of Indiana, data on assessed valuation of properties need not be kept beyond ten years. Because such appraisals are made every 3 or 4 years, there may be only two or three data points with which to create a trend of property values. Users of these data must also be aware of any changes in the rules by which property values have been assessed. 


\section{Absolute Amount of Poverty in an Economy \\ Advantages:}

Easily obtained through databases. This measure uses income data that can be obtained through various databases such as the U.S. Census Bureau.

Standardized threshold across the country. The Health and Human Services Poverty Guidelines provides a standardized threshold that is consistent throughout the country. This allows for an objective measure to indicate economic development and stability.

Disadvantage: Does not indicate community profile (wealthy area versus poor area). While the measure provides information regarding the percentage of households classified as poverty level, it does not provide information regarding the overall status of a community. A rural area could still be a 'poor' area even if the percentage of households in poverty is low. This measure only looks at the extreme end of the spectrum. The remaining units of poor to extremely wealthy cannot be determined from this measure. Another way to measure income distribution would be to use the Gini Coefficient. This technique provides a statistical method to determine the distribution of wealth (income). However, similar limitations apply. Only distributions within the given set are calculated, the level of the set (poor, middle class, or wealthy) is not revealed in this method.

\subsection{Refining the Tentative List of Performance Measures}

The 12 economic development performance measures (PMs) presented above are taken from a longer list generated by a review of the literature. These PMs were identified as being most applicable to decision-making regarding possible transportation investments in rural areas. Advantages and disadvantages of each PM have been presented to permit a tentative ranking of the PMs for use by INDOT. However, further analyses would help to verify, reorder, supplement, or replace these PMs. The kinds of analyses that would have been completed had this project continued are outlined briefly in Chapters 5 and 6 . A steppingstone to those analyses is a look at how economists have approached related issues. This approach is summarized in the next chapter. 


\section{CHAPTER 4: THE ECONOMIST'S PERSPECTIVE}

At the project's SAC meeting on Monday 27 October 2008, some SAC members asked the researchers to look into the economist's view of performance measures that may assist decisions regarding transportation investment in and for rural areas. At the time of the SAC meeting, the researchers had assembled a list of performance measures (see the previous chapter) that they thought were reasonable candidates to be considered for the objectives of the project. To supplement their initial appraisal of the pros and cons of each performance measure (PM), they had begun to seek data to apply to each PM. If the data were difficult or impossible to obtain, of course that PM would be of little value to us or to INDOT. The early stage of this analysis is described in the next chapter.

\subsection{Purdue University's Center for Rural Development}

An excellent source for the economist's viewpoint is Purdue University's Center for Rural Development (CRD) at http://www.agecon.purdue.edu/crd/index.htm. SAC member Patrick Long provided a link to a CRD paper, "Industry Linkages and the Structure of the Local Economy", by Daniel V. Rainey and Kevin T. McNamara, ca. 1997. The paper examined the relative economic impacts of (a) an expansion to an existing company and (b) the introduction of a new company in an area. The focus was on counties that contained metropolitan areas or were adjacent to such counties. Rural ("non-adjacent") counties were not the focus of this paper. Table 1 in the paper contained a list of variables that were used in the local economic impact models. Most these variables had to do with "basic" employment in various sectors of the economy. These variables could be used as performance measures, if the data are available. The only transportation-related variable was "miles of interstate highway in the county". If INDOT wants to predict the rural economic impacts of non-Interstate highway projects, the model in this paper would not help.

The project PI contacted two members of the Center -- Profs. Larry DeBoer and Kevin McNamara. Prof. DeBoer said that his specialty is in Fiscal Impact Models, but that Prof. McNamara probably had the expertise that the SAC wanted. Prof. McNamara has spent almost twenty years looking at factors that affect the location decisions of various manufacturing firms. During the first telephone conversation, Prof. McNamara cited two of his early papers:

- "Recruiting Manufacturing Firms as a Community Development Strategy", Kevin T. McNamara, EC659, Purdue University, Cooperative Extension Service, ca. 1991. "A large population, significant economic activity, labor availability and quality, existence of air and highway transportation facilities, availability of quality industrial site, and the existence of local public services were important location factors in most of the research cited. Larger communities with an available labor force, an existing manufacturing base, and access to facilities associated with metropolitan areas appear to be the communities that will be most successful in attracting new industry. Rural counties, which tend to have smaller populations, less labor availability, smaller existing manufacturing, and fewer local services, are at a disadvantage in competing against larger communities for manufacturing investment." "Rural communities with a low probability of 
attracting new manufacturing investment should consider other development strategies offering greater potential for local economic growth. These strategies include retention and expansion of existing business and industry, recreation and tourism development, and local business development."

- "A COUNTY-LEVEL MODEL OF MANUFACTURING PLANT RECRUITMENT WITH IMPROVED INDUSTRIAL SITE QUALITY MEASUREMENT", Warren Kriesel and Kevin T. McNamara, July 1991. The authors developed a model that would predict the probability that a county would attract one or more plants to locate there. Based on Georgia data, the "community-controlled variables" were high school graduation rates, fire protection, tax rate, and price of industrial land. Under "noncontrolled location variables" were wage rate, unemployment rate, number of manufacturing employees, miles of interstate highway, percent black residents, and distance to a college. Because the objective was to explain the behavior of those who had made location decisions regarding manufacturing plants, the variables were not conducive to application as performance measures.

In a subsequent email, Patrick Long cited the Urbanophile blog (2008). The article there was not upbeat about economic development in rural areas in Indiana. "The new economy we are in favors big cities over small ones and rural areas." "There seems to be some sort of minimum scale necessary to support an economy that can compete in the 21st century. As a rule of thumb, I set that level at around one million in a metro area, though I think smaller places can succeed in certain instances. In that regard, Indiana needs to adopt metro-centric thinking in how it develops economic development strategies."

In the PI's second phone conversation with Prof. McNamara, he said that he had developed a location model based on Virginia data around 1990, which led to the Kriesel and McNamara paper described above. If put into a spreadsheet, it could help an analyst answer "what if" questions about improving the probability that a county would attract a manufacturing plant. The user would have to be aware, however, that the model was based on Virginia data.

Prof. McNamara provided the PI with his (and Dayton Lambert's) latest paper (under review by a journal), which has the intriguing title "Determinants of Food Manufacturing Investment: Are Nonmetropolitan Counties Competitive?". Based on Indiana data, the authors conclude that "Local community attributes influence the location choices of food manufacturers. Population, ... labor quality, and workforce trainability are important site selection determinants for food manufacturers locating in nonmetropolitan counties. Very remote nonmetropolitan counties do not have comparative advantage with respect to attracting food manufacturers. All food processor types select locations in or around urban areas, or in nonmetropolitan counties that provide access to product or input markets, or agglomeration economies. Supply oriented firms tend to locate in nonmetropolitan counties providing access to agricultural inputs." "Rural communities already endowed with a manufacturing base may find that spending scarce development resources on projects geared toward retaining businesses will produce better payoffs in the long-run." Prof. McNamara said that he has data for all manufacturing types in Indiana. 
Prof. McNamara also mentioned a paper that he co-authored with Joseph Broder on the economic impact of developmental highways in Georgia. However, Prof. McNamara said that a principal finding was that new highways into rural areas do less to stimulate economic development in the newly-served locations than they serve as "escape routes" for residents to access opportunities in larger communities. This coincides with some of the thinking that led the researchers to add certain PMs to their list. A new road can bring amenities that are more likely to be found in urban areas closer to rural residents. This also adds value to the researchers' interest and work on Quality of Life measures. If economic development in rural areas is as difficult to bring about as some economists think, perhaps an emphasis

on Quality of Life in rural areas should be considered. See Chapter 6 for some early thoughts on Quality of Life measures.

Prof. McNamara's other remarks on the phone included:

- Although Nadia Gkritza's thesis work (2007) was not aimed at rural areas, she collected some primary survey data that may be useful for this project. [Nadia's project was FHWA/IN/JTRP2006/37, "Economic Development Effects of INDOT Transportation Projects", SPR-2861. The end product of her research was a quantitative tool that can be used at the project development phase to estimate the statewide long-term economic effects of highway investment in Indiana.]

- Labor as a cost of production is less important than it used to be in a company's location decision. The availability of services has become more important.

- Recent experience during economic downturns has shown that rural plants are decommissioned, while plants in more urban settings suffer "only" temporary layoffs.

\subsection{Observations and Findings}

The PI's conversations with Prof. McNamara and the PI's reading of the papers recommended by Prof. McNamara lead to the following observations:

1. The economist seeks to explain location choice by private firms in terms of a variety of plausible factors, only one of which is transportation-related. Understanding this decision process may be helpful to INDOT, but that is a much different direction and wider scope than the original objectives of this project. The researchers on this project are capable of applying the coefficients that they have found in old studies to current Indiana cases, but the models that the researchers have found tend to be based on data from other states and decades. Prof. McNamara has the experience and expertise to construct newer models toward that end, if that is INDOT's desire.

2. The economist-oriented research activities that the researchers have undertaken since the SAC meeting of Monday 27 October 2008 have been instructive as to (a) glimpsing the economist's viewpoint and (b) reviewing the variables or factors that have been employed in analyzing rural economic development. This experience can provide a better context in which to evaluate the performance measures that have been collected from the literature searches and interviews.

3. There would have been value in allowing the researchers to complete their evaluation of the performance measures that are listed and discussed in the previous chapter. The plan was to do so by attempting to apply real data to a selection of rural counties in Indiana, as described in the next chapter. As this would have been done, it would have been possible to consider variations on the 
transportation-related variables found in the literature. For example, the "miles of interstate highway in the county" variable has several weaknesses with respect to the objectives of this project. One alternative seems to have merit: The distance (or travel time) from the population center of a rural county to the nearest interstate highway. The definition needs to be tested and refined, but it holds promise as a way to distinguish some rural counties from others as part of an INDOT project selection process.

4. Based on some of the opinions of economists found in the researchers' recent readings in the literature, a consideration of objectives besides traditional economic development in rural areas may be called for. Although this was not part of the project's scope, an investigation of Quality of Life measures is a logical response to the "escape route" findings cited above and a natural companion to the Performance Measures being evaluated in the project. This is described briefly in Chapter 6.

\subsection{Work Left Undone}

After the researchers submitted to the Study Advisory Committee their findings regarding "the economist's perspective", the project was halted. The chapters that follow introduce the activities that had been initiated at the time the project was stopped. Because of the circumstances involved, the work on the tasks described is incomplete and the description is necessarily truncated. 


\section{CHAPTER 5: PROSPECTS FOR IMPLEMENTATION}

Twelve economic development performance measures were identified in Chapter 3 as having the greatest potential for use when evaluating transportation investments in rural areas. This assessment was based on a search of the published literature on PMs in general, most of which were not specifically developed for application to rural cases. The researchers reduced the list of PMs to twelve by applying their knowledge of Indiana and the particular nature of rural areas. Once this was done, the researchers wanted to test their tentative list of 12 against specific real cases in Indiana. At the time this project was halted, research had begun on (1) county-level data analysis, (2) individual case studies, and (3) quality of life issues. The first two activities will be described briefly in this chapter. The Quality of Life activity will be introduced briefly in Chapter 6 .

\subsection{County-Level Data Analysis}

To test the twelve performance measures that were identified and critiqued in Chapter 3, a technique used by Mills and Fricker (2008) to evaluate the impacts of bypass highways on Indiana counties was to be applied to rural counties that have had major transportation projects. The bypass study used statistical analysis techniques to identify factors that explained economic impacts of a bypass at the county level. The explanatory factors found by Mills and Fricker can guide the decision-making process when a bypass is proposed. Several dependent variables were tested. Those with the strongest predictive value could be considered as strong candidates for use as performance measures. In the rural context, this analysis could be repeated with the twelve PMs identified in Chapter 3 and with any other economic indicators that showed promised in the bypass study. By being able to carry out such an analysis on data collected rural counties, the availability of data needed to evaluate rural transportation investments is confirmed. The results of the analysis would show the strength of the connection between independent and dependent variables. It may also make it possible to compare counties based on the need for economic development as well as the probability of development.

Data were being obtained for Dubois, Perry, Brown and Greene County to validate each nominated performance measure, as well as to make possible the statistical analyses ...

\subsection{Individual Case Studies}

Case studies can be helpful when evaluating the effectiveness of each measure to accurately identify the economic development resulting from a specific transportation investment. In a recent study of the impacts of bypasses on Indiana communities (Mills and Fricker 2008), a case study approach was found to be a valuable complement to the quantitative analyses of the economic impacts. Interviews of key

individuals in the bypassed communities identified factors that could not be captured by numbers alone, and also helped explain some aspects of the quantitative models.

During the course of this project, transportation investments in rural areas of Indiana were identified for use in a case-by-case evaluation using the performance measures listed previously. A list of 25 projects 
(Table 5.1) was provided by INDOT personnel. The projects were separated into four different groups. Group A projects are traditional added travel lanes (ATL) projects that have been improved from 2-lane to 4- or 6-lane roads. Group B includes reconstruction of horizontal or vertical curves due to substandard alignments. Group $C$ includes projects under construction at this time, with Group D identifying those projects that are scheduled for the near future.

Table 5.1 INDOT projects in rural counties

Source: John Curry, INDOT Vincennes District

Group A:

1) I-164 from US 41 at the south edge of Evansville in Vanderburgh County to I-64 near the Vanderburgh/Gibson/Warrick County lines. This was a completely new road built as a bypass of Evansville. Four-lane road built between 1988 and 1991.

2) SR 62 from I-164 to Chandler in Warrick County. Existing 2-lane is now a 4-lane. Completed between 2006 and 2008.

3) SR 66 from I-164 to SR 261 in Warrick County. This section was a 2-lane and is now a 6-lane roadway. Completed in 2006.

4) SR 37 from US 50 in Lawrence County to Monroe County Line. New road built as bypass of Bedford. Four-lane completed in 1974.

5) SR 37 in Lawrence County from SR 60 at Mitchell to US 50 at Bedford. Existing 2-lane relocated and made into 4-lane. Completed in 1994.

6) SR 66 from West side of Evansville to just west of Posey County Line. 4-lane completed in 1969.

7) US 231 from Ohio River Bridge in Spencer County to SR 70. Completed in 2006.

8) US 50 from Illinois Line to East of Washington in Knox and Daviess Counties. New 4-lane. The incennes Bypass section was completed in 1967. The remaining sections were started in 1997 and completed in 2000.

9) I-64 from Illinois line to SR 66 in Crawford County. Completed in the mid to late 1970's. New 4-lane interstate.

10) SR 62 from Mt. Vernon in Posey County to Evansville in Vanderburgh. Completed in late 1960's.

Group B:

1) SR 37 in Crawford and Perry Counties from I-64 to SR 64. New 2-lane road just completed in 2007.

2) SR 69 in Posey County from SR 62 at Mt. Vernon to I-64. This was built in 4 phases, the most southern phase being a bypass of Mt. Vernon. The other 3 phases are rural and were built near the same alignment but was a newly constructed road. Last phase of this two-lane completed in 2000. 3) SR 67 from US 41 to Bicknell in Knox County. 2-lane road completely reconstructed on same alignment with added truck lanes. Completed in 2005.

4) SR 37 in Perry County from Tell City to I-64. Two-lane road completed in 1981.

5) SR 145 from SR 64 in Crawford County to SR 56 at French Lick/West Baden in Orange County. Twolane road constructed in mid 1970s.

Group C:

1) SR 66 in Warrick County for SR 261 to Old SR 662. Project just let. Will convert 2-lane to 4-lane.

2) US 231 in Spencer County. Building a new 4-lane bypass of Dale and new interchange at I-64.

3) I-69. We just let a 2 mile contract from I-64 to SR 68. New 4-lane Interstate. 
Group D:

1) SR 261 in Warrick County from SR 66 to Jenner Road, approx 3 miles in length. Two-lane road to become four-lane. Scheduled to start in 2010.

2) SR 66 from Old SR 662 to just east of SR 61 in Warrick County. Existing 2-lane to become 4-lane. Scheduled for 2009. Will complete corridor from Evansville to the existing 4-lane in Warrick and Spencer counties.

3) SR 62 from Chandler to Boonville in Warrick County. 2-lane to become 4-lane. Scheduled for 2009. Will completed corridor from Evansville to Boonville.

4) US 231 from SR 70 to Dale Parts of this road are completed and the other section will be let in 2009. Old 2-lane road being converted to 4-lane. This will complete corridor from Ohio River Bridge to I-64. 5) I-69 for SR 68 in Gibson County to SR 37 near Bloomington. Future lettings. No dates set. New 4lane interstate.

6) SR 61 Boonville Bypass. Will start at current SR 62 and SR 61 jct on the west side of Boonville in Warrick County, go around the west side of the city and tie in a couple of miles north on existing SR 61. Scheduled for 2013.

7) US 231 Huntingburg-Jasper Bypass in Dubois County. This would be a 4-lane bypass beginning at the currently under-construction section at I-64 and bypass Huntingburg and Jasper on the East and tie back into US231 north of Jasper. Only a portion of this Bypass is currently funded.

By getting "qualitative" information from a sample of the counties represented in Table 5.1, several issues about performance measures (PMs) can be examined:

Which of the PMs already identified match more closely with what is important to local stakeholders?

Do any of the PMs considered important by local stakeholders differ from those preferred by INDOT decision-makers?

Do the interviews with local stakeholders reveal any new PMs?

As the bypass project indicated, a purely quantitative analysis may miss some important elements that must be part of a decision-making process ...

\subsection{Lessons for Implementation}

The findings that could be generated by the two analyses described in this chapter would have the advantage of being based on real cases in Indiana. The lessons learned in the process would enhance the prospects for successful implementation of the findings. 


\section{CHAPTER 6: QUALITY OF LIFE MEASURES}

Performance measures oriented toward the economic indicators for a particular rural area may not give a complete picture of the success or failure of a transportation investment. McNamara and Kriesel's 1991 study of the economic impact of developmental highways in Georgia found that improved access to rural areas may provide an "escape route" for rural residents to travel to larger cities for economic purposes. If the intended purpose of a transportation investment is to provide a stimulus for economic development in a rural area, it may provide the opposite effect, if the investment is treated as "a way out" of the rural community by its residents rather than "a way in" for businesses and travelers. This is not necessarily a bad thing. A rural area may be able to retain (or even grow) its population it if becomes less isolated from the employment and amenities that more populated areas can offer. A rural area that is stable or growing thanks to a transportation investment can be considered an economic success, even if the rural area does not attract basic industry.

At the time this project was stopped, Quality of Life (QoL) measures were being identified and critiqued. (Table 6.1) A methodology was being formulated to evaluate QoL effects of transportation investments. This methodology is similar to that of economic development performance measures, where measures are being identified and compiled for further evaluation. Due to the subjective nature of quality of life, steps must be taken to account for this variability. Because the way factors affect quality of life differs between individuals, a market segment approach may have to be adopted.

Table 6.1 Quality of Life Measures

\begin{tabular}{|c|c|c|c|c|c|}
\hline Indicator & Definition & Source/Reference & Where Applied & Advantages & Disadvantages \\
\hline $\begin{array}{l}\text { Population } \\
\text { Growth }\end{array}$ & $\begin{array}{l}\text { Strongest growth } \\
\text { in population from } \\
2000 \text { to } 2005\end{array}$ & Bizjournal.com & $\begin{array}{l}577 \\
\text { micropolitan } \\
\text { areas in } \\
\text { America }\end{array}$ & $\begin{array}{l}\text { 1. Easy to } \\
\text { obtain } \\
\text { 2. Easy to } \\
\text { understand }\end{array}$ & $\begin{array}{l}\text { 1. Is growth always } \\
\text { good? } \\
\text { 2. Cut off value to } \\
\text { determine good/bad } \\
\text { growth? }\end{array}$ \\
\hline $\begin{array}{l}\text { Income } \\
\text { Growth }\end{array}$ & $\begin{array}{l}\text { Strongest growth } \\
\text { in per capita } \\
\text { income from } 1999 \\
\text { to } 2004\end{array}$ & Bizjournal.com & $\begin{array}{c}577 \\
\text { micropolitan } \\
\text { areas in } \\
\text { America }\end{array}$ & $\begin{array}{l}\text { 1. Easy to } \\
\text { obtain } \\
\text { 2. Easy to } \\
\text { understand }\end{array}$ & $\begin{array}{l}\text { May hide other } \\
\text { factors such as } \\
\text { white vs. blue collar } \\
\text { jobs or the \# of jobs }\end{array}$ \\
\hline $\begin{array}{l}\text { Per Capita } \\
\text { Income }\end{array}$ & $\begin{array}{l}\text { Highest per capita } \\
\text { income }\end{array}$ & Bizjournal.com & $\begin{array}{c}577 \\
\text { micropolitan } \\
\text { areas in } \\
\text { America }\end{array}$ & $\begin{array}{l}\text { 1. Easy to } \\
\text { obtain } \\
\text { 2. Easy to } \\
\text { understand }\end{array}$ & $\begin{array}{l}\text { 1. May hide other } \\
\text { factors such as } \\
\text { white vs. blue collar } \\
\text { jobs or the \# of jobs } \\
\text { 2. What is good? } \\
\text { Are } 2 \text { small } \\
\text { businesses better } \\
\text { than one large } \\
\text { business? Is there } \\
\text { an optimum value? }\end{array}$ \\
\hline
\end{tabular}




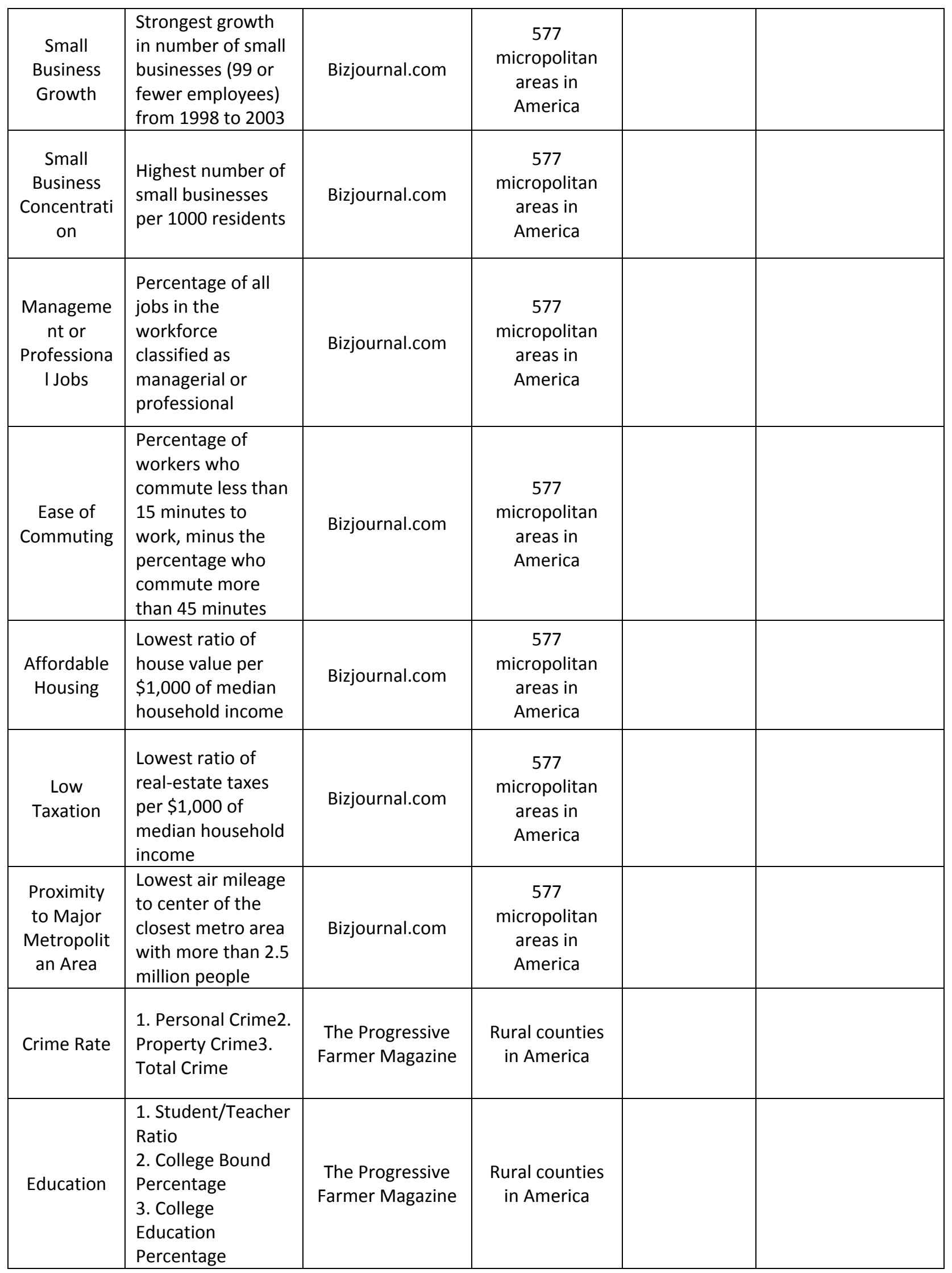




\begin{tabular}{|c|c|c|c|c|}
\hline $\begin{array}{l}\text { Economic } \\
\text { Factors }\end{array}$ & $\begin{array}{l}\text { 1. Avg. HH Income } \\
\text { 2. Avg. HH } \\
\text { Spending } \\
\text { 3. County Sales Tax } \\
\text { 4. Avg. home price } \\
\text { 5. Job growth } \\
\text { 6. Unemployment } \\
\text { 7. Poverty } \\
\text { percentage }\end{array}$ & $\begin{array}{l}\text { The Progressive } \\
\text { Farmer Magazine }\end{array}$ & $\begin{array}{l}\text { Rural counties } \\
\text { in America }\end{array}$ & $\begin{array}{l}\text { 1. saving rate could } \\
\text { be misleading } \\
2 . \text { Is there } \\
\text { distinction between } \\
\text { those receiving } \\
\text { assistance vs. self- } \\
\text { supported } \\
\text { individuals? }\end{array}$ \\
\hline $\begin{array}{l}\text { Access to } \\
\text { Health Care }\end{array}$ & $\begin{array}{l}\text { 1. Health Density } \\
\text { 2. \# of Hospitals } \\
\text { 3. \# of Clinics } \\
\text { 4. \# of Pharmacies }\end{array}$ & $\begin{array}{l}\text { The Progressive } \\
\text { Farmer Magazine }\end{array}$ & $\begin{array}{l}\text { Rural counties } \\
\text { in America }\end{array}$ & $\begin{array}{l}\text { Definition of health } \\
\text { density is subjective }\end{array}$ \\
\hline Climate & $\begin{array}{l}\text { 1. Air Quality Index } \\
\text { 2. Annual Rainfall } \\
\text { (in) } \\
\text { 3. Min. Jan. Temp. } \\
\text { (avg) } \\
\text { 4. Max. July Temp. } \\
\text { (avg) }\end{array}$ & $\begin{array}{l}\text { The Progressive } \\
\text { Farmer Magazine }\end{array}$ & $\begin{array}{l}\text { Rural counties } \\
\text { in America }\end{array}$ & $\begin{array}{l}\text { 1. Not significant } \\
\text { difference within } \\
\text { state } \\
\text { 2. People may have } \\
\text { different opinions } \\
\text { regarding } \\
\text { distribution of } \\
\text { temperatures }\end{array}$ \\
\hline Culture & Leisure Index & $\begin{array}{l}\text { The Progressive } \\
\text { Farmer Magazine }\end{array}$ & $\begin{array}{c}\text { Rural counties } \\
\text { in America }\end{array}$ & $\begin{array}{l}\text { 1. Difficult to obtain } \\
\text { 2. Subjective } \\
\text { measurement }\end{array}$ \\
\hline Health & $\begin{array}{l}\text { Life expectancy at } \\
\text { birth, years }\end{array}$ & $\begin{array}{c}\text { Economist } \\
\text { Intelligent Unit }\end{array}$ & $\begin{array}{l}111 \text { different } \\
\text { countries }\end{array}$ & \\
\hline Family Life & $\begin{array}{l}\text { Divorce rate (per } \\
1,000 \text { population), } \\
\text { converted into } \\
\text { index of } 1 \text { (lowest } \\
\text { divorce rate) to } 5 \\
\text { (highest) }\end{array}$ & $\begin{array}{c}\text { Economist } \\
\text { Intelligent Unit }\end{array}$ & $\begin{array}{l}111 \text { different } \\
\text { countries }\end{array}$ & \\
\hline $\begin{array}{c}\text { Job } \\
\text { Security }\end{array}$ & $\begin{array}{l}\text { Unemployment } \\
\text { rate, \% }\end{array}$ & $\begin{array}{c}\text { Economist } \\
\text { Intelligent Unit }\end{array}$ & $\begin{array}{l}111 \text { different } \\
\text { countries }\end{array}$ & \\
\hline
\end{tabular}

There have been numerous attempts at developing Quality of Life (QoL) measures. Newspapers and magazines frequently rank urban areas for "liveability", retirement climate, etc. In this project, the challenge would be to develop QoL measures than can be combined with economic PMs. The data that contribute to the QoL measures and PMs must be reasonably accessible and have sufficient explanatory power to assist decision-makers at INDOT in choosing between competing transportation projects. 


\section{CHAPTER 7: RESULTS AND RECOMMENDATIONS}

While this study on economic development performance measures had begun to produce a good framework when it was interrupted, it is evident that additional research needs to be completed to provide a better understanding of the link between transportation investment and economic development. Researching case studies, county-level data, and quality of life issues can help to provide that critical link in order to assist INDOT in choosing between transportation projects in the future.

This report is intended to guide further research in the area of economic development, particularly in rural areas of Indiana. Twelve economic development performance measures have been identified as the most effective measures to use when evaluating a transportation investment. However, further analysis of each measure is needed to provide a solid foundation for performance measure implementation in project evaluation.

At this point in the research, seven of the twelve performance measures identified would be recommended for use immediately by economic development personnel. These measures are business expansion, business retention, number of jobs, total income, average income, output per capita, and absolute amount of poverty in an economy. These measures are recommended based upon ease of data collection, ease of interpretation, and direct application to economic development. The remaining five measures (capital investment, economic stability, number of activities, number of businesses, and property appreciation) also provide a link to economic development, but are not included for immediate use due to lack of data and/or subjectivity of interpretation. These measures should be used on a caseby-case basis only when particularly applicable to the economic evaluation. If the Works in Progress (Chapters 5 and 6 ) could have been pursued, these performance measures could have been further validated, replaced, or complemented. 


\section{REFERENCES CITED}

Eberts, R. (2000). Understanding the Impact of Transportation on Economic Development. Retrieved 2

April, 2008, from Transportation Research Board: www.trb.org/publications/millennium/00138.pdf

Farlex, I. (2008). Definition of Job. Retrieved April 2, 2008, from The Free Dictionary:

http://www.thefreedictionary.com/job

Gkritza, N., S. Labi and K. Sinha (2007) “Economic Development Effects of INDOT Transportation Projects”, FHWA/IN/JTRP-2006/37, SPR-2861, May 2007.

Hillstrom, N. L. (2005). Legal Definitions. Retrieved April 2, 2008, from USLegal, Inc.:

http://definitions.uslegal.com/b/business-expansion/

Kriesel, Warren and Kevin T. McNamara (1991), “A COUNTY-LEVEL MODEL OF MANUFACTURING PLANT RECRUITMENT WITH IMPROVED INDUSTRIAL SITE QUALITY MEASUREMENT", http://ageconsearch.umn.edu/bitstream/30281/1/23010121.pdf, July 1991.

Lambert, Dayton and Kevin T. McNamara (2008), "Determinants of Food Manufacturing Investment: Are Nonmetropolitan Counties Competitive?", unpublished manuscript, Purdue University.

McNamara, Kevin T. (1991) "Recruiting Manufacturing Firms as a Community Development Strategy", EC-659, Purdue University, Cooperative Extension Service, http://www.ces.purdue.edu/extmedia/EC/EC-659.html.

McNamara, K. and Kriesel, W. (1991). A County-Level Model of Manufacturing Plant Recruitment with Improved Industrial Site Quality Measurement. Southern Journal of Agricultural Economics Association.

Mills, J.B. and Fricker, J.D. (2008). "Effects of Bypasses", SPR-3094, Draft Final report under review.

The Network. (2007). Retrieved February 4, 2008, from The Access Project:

http://www.atdn.org/access/poverty.html

Pickton, T., Clements, J., and Felsburg, R. (2007). Statewide Economic Benefits of Transportation Investment. Denver: Colorado Department of Transportation Research Branch.

Rainey, Daniel V. and Kevin T. McNamara, (1997?), "Industry Linkages and the Structure of the Local Economy", Center for Rural Development, Purdue University, http://www.agecon.purdue.edu/crd/htmlfiles/doc16.html

Singh, L., Gkritza, N., and Sinha, K. (2007). Economic Development Performance Measures and Rural Economic Development in Indiana. West Lafayette: Purdue University. 
Urbanophile (2008). A New Approach to Regional Economic Development in Indiana. Retrieved November 4, 2008, http://theurbanophile.blogspot.com/2008/10/new-approach-to-regionaleconomic.html.

Ward, B. G. (2005). Measuring the Effectiveness of Community Impact Assessment: Recommended Core Measures. Tampa: University of South Florida.

Weisbrod, G. (2000). NCHRP Sythesis 290: Current Practices for Assessing Economic Development Impacts from Transportation Investments. Washington, D.C.: National Academy Press.

Weisbrod, G. and Forkenbrock, D. J. (2001). NCHRP Report 456: Guidebook for Assessing the Social and Economic Effects of Transportation Projects. Washington, D.C.: National Academy Press. 